\title{
Knowledge Management and Changing Psychological Contracts
}

\section{Main Description}

The literature on knowledge management has been curiously silent about the role of knowledge management as a method of supporting a neo-liberal agenda of organizational anorexia and professional disempowerment. This paper suggests that the impact of knowledge management praxis needs to be considered in the light of a changing psychological contract that may have detrimental effects on both individuals and organisations.

\section{Short Description}

This paper discusses the changing psychological contract at work and its relationship to knowledge management praxis.

\section{Keywords}

Knowledge management.

Psychological contract.

Intellectual property.

Change.

Work.

Word Count 3929 


\section{Introduction: Knowledge Management Pre-requisites Meet “Anorexic” Organizational Realities}

This paper considers a hitherto neglected issue in the knowledge management literature, that of the psycho-social effects of the resocialisation of work of which knowledge management is a component. The construct of the psychological contract is used as a means to explaining the psycho-social effects associated with this phenomenon.

Constructing, transforming and commodifying information and knowledge require new organizational understandings and newer cognitive capabilities of human resource management praxis. For years, organizations paid lip service to the management of knowledge, being concerned with more tangible and physical assets. The knowledge component of the value-chain had been obscured by the tendency to think of work as fundamentally a physical activity (Zuboff, 1988). However, the potential advantages that intellectual capital brings in the form of greater earnings through licensing technology has revised this trend. Intellectual assets exist in various forms and their exploitation is only restricted by the capacity of humans to so. The capacity to manage the human intellect and convert it into useful products and services is fast becoming the critical executive skill in the contemporary organization (Davis, 1998). There has been an intense interest in intellectual capital, creativity, innovation and the learning organization. Yet, research shows that few organizations have realized benefits from knowledge management initiatives (Murray and Myers, 1997; Brue, Grimshaw and Myers, 2000). One of the reasons for this may be that there is no coherent framework for implementing the management of knowledge in an organisation. More specifically knowledge management praxis has failed to consider human resource implications.

One of the largely unwritten reasons for the rise of knowledge management has been downsizing and the casualization of the workforce fuelled by the dogma of neo-liberalism. The knowledge management literature is focused on seeking ways to access, records, save and pass on the intellectual property of workers. That these workers might be casual staff, consultants or staff with no guarantee of tenure seems to have escaped the rush to exploit their intellectual property. How employers and employees understand intellectual property rights is an important component of the modern psychological contract and an area that has been ignored in the knowledge management literature and practice.

In developing the anorexic organization, the effect on the individual has almost been forgotten. Here, we are specifically concerned here about the psychological impact that knowledge management praxis might have on workers who are 
increasingly being asked to not only give up employment security, they are also being asked to surrender all that they own, their intellectual property.

There is a growing body of literature that suggests that the implicit psychological contract typically held with employees - job security in exchange for "loyalty" - is changing. Employees no longer acknowledge the existence of an implicit or explicit psychological contract between themselves and their employer. This paper aims to address the notion of the "new" psychological contract and work externalization, given that change is acknowledged as stressful and that employees have to learn to cope with such stress and employers need to provide opportunities for further development and re-employability.

\section{The Psychological Contract}

According to Rousseau and Greller (1994), a psychological contract is defined as the individual's beliefs regarding the terms and conditions of an exchange agreement between that person and another party. A balanced psychological contract is a pre-requisite for an on-going and harmonious relationship between an employee and the organization. The "balance" of the psychological contract is largely dependent on two conditions. First, it depends on the degree to which employees' expectations of what the organization will provide, and what is owed in return, match the organization's expectations of what it will give and get (Sims, 1994) - labelled as "reciprocal expectancy". Secondly, the balance of the psychological contract depends on whether or not there is agreement on what is actually to be exchanged between the employee and the organization (Korac-Kakabadse and Korac-Kakabadse, 1998). Examples include money in exchange for time at work; social need satisfaction in exchange for work; and, until recently, security in exchange for work and loyalty - labelled as "reciprocal exchange".

The psychological contract is an implicit agreement between employer and employee that each party will treat the other fairly; it is based on presumably shared beliefs (Schein, 1980; Schermerhorn, Hunt and Osborn, 1985; Tornow, 1988). Because it is unwritten and unofficial, and therefore not legally binding, the motivation for compliance is not, as it is with explicit written contracts, the fear of legal reprisal but, rather, the desire to maintain mutual trust. It, thus, constitutes an essentially emotional bond (which is one reason why, when broken, people experience deep, long-lasting feelings of betrayal and resentment). More recently Rousseau (1994; 2001) has emphasized the importance of the formation of schema in the minds of employees about the nature of the agreement between they and the employer and that this agreement is mutual and binding. The psychological contract, therefore, is promise-based. As a consequence, a violation of this contract results in more intense attitudinal and emotional responses than even unmet expectations (Rousseau, 2001). 
What makes psychological contracts more complicated, however, is that they are dynamic and highly subjective (Hiltrop, 1996) so that people make additions to the contract 'as they go along'. Impressions are made from the way others are treated, from conversations and from the behaviour of those in control. While Schein (1980) and Rousseau (2001) acknowledge the role of schema in the development of psychological contracts little has been said about the expectations or needs of the individual. The need for approval, for example, is an underpinning principle in Theory Y behaviour or organizations (McGregor, 1960). Some people need more recognition than others and some react with extreme anger or anxiety when their ego is threatened by some external behaviour.

The rest of this paper explores the change in the psychological contract asks how these changes need to be considered in terms of intellectual property and knowledge management. In particular we are concerned about the effect on the individual when they become aware that a breach of the contract has occurred and how organizations might prevent this from occurring.

\section{The Changing Nature of Work and the Psychological Contract}

An economy that adds value through information, ideas and intelligence, the "Three-I Economy", also introduces different work arrangements. For example, in the European Union, one half of the available workforce is outside traditional work arrangements - this is, not in full-time jobs (Handy, 1995). The median employment tenure of US workers is just four and half years and for executives, managers and professionals just six years (Magurie, 1993).

As Korac-Kakabadse, Korac-Kakabadse and Kouzmin, 1998a; 1998b) summarize, due to economic pressure (permanent un-employment, permanent under-employment, decline of middle class); changing business needs (shift from products to services, shift to human-based services, focus on core business, cost reduction, customer focus); demographic changes (femaledominated workforce, aging workforce, decline in youth population); organizational dynamics (globalization, minimalist/line organization, externalized work, demise of traditional organization, demise of traditional management); social change (increased affluence, post-materialistic values, emerging leisure society); and technology advancement (invisible collaboration, virtual companies/teams, global communication/interaction, personal corporate infrastructure, mobility and opaque work domains), the social and psychological contract between employee and employer has been eroded. 
The erosion of the psychological contract is two-fold; at the functional and organizational level. At the functional level, where this erosion is less visible, the permanent workforce is losing its identification with functional loyalty due to the work of multi-task teams and streamlining processes. The erosion in the externalized workforce is more visible as loyalty to the organization is disappearing. Organizational cuts are powerful because they can determine how well a business performs and they also provide individuals with a sense of meaning through experience in a particular context. Organizations provide a genius loci or "spirit of place" in terms of an "orientation" and knowing where one is in relation to one's context and in terms of "identification", involving knowing how one is able to relate to action place (Schulz, 1980).

Implicit psychological contracts held with employees, such as job security in exchange for "loyalty", are changing, if not being destroyed (Hiltrop, 1996; Maguire, 2002; Moskal, 1993; Morrison, 1994). For those who move beyond the known, structured organization there is a new world, that of the consultant. Relying on networks, short term contracts and an even lower level of job security the psychological contract between the consultant and employer is even more problematic.

Considering that a critical dimension of the employee-employers interaction is the psychological contract, the impact and change between parities of factors such as social support, promotion prospects and job satisfaction in return for, perhaps, organizational commitment and organizational socialization (Rousseau and McLean Parks, 1993), will need to be identified and re-negotiated in times of change and new ways of working.

Under the new covenant, employers give individuals the opportunity to develop greatly enhanced employability in exchange for better productivity and some degree of commitment to company purpose and community for as long as the employee works there. It is the employee's responsibility to manage his or her own career, while it is the company's responsibility to provide employees with the tools, the open environment and the opportunities for assessing and developing skills (Korac-Kakabadse and Korac-Kakabadse, 1998). Employees are beginning to recognize that they can expect to have multiple careers and that they have more responsibility for assessing and designing their own careers (Sims, 1994). Another important issue is the effect of the changed psychological contract on job satisfaction and employee commitment (Lucero and Allen, 1994; Logan, O’Reilly and Roberts, 1973; Rogers, 1995; Miller and Terborg, 1979). 
Feldman, Doerpinghaus and Tumley (1994) identified six key concerns of externalized employees, four of which have implications for the "new" psychological contract. The first concerns the impersonal way in which externalized employees are treated on the job. This issue highlights the psychological dynamics associated with a dual labour market structure which consists of a permanent or core workforce alongside a peripheral (or externalized) pool of employees. Peripheral employees run the risk of being socially marginalized as a result of their "outsider" status. The second concern was that externalized employees felt insecure about their employment and were pessimistic about their future. The third concern was that such employees fared poorly with regard to insurance and pension benefits. The fourth area of concern was the claim made by temporary employees that employers failed to provide an accurate picture of their job assignments. Here, there is a direct reference to the notion of reciprocal expectancy. Organizations were not providing accurate (or honest) information on what they would provide and what is owed in return. This, coupled with the lack of exchange factors resulting in the erosion of the condition of reciprocal exchange, points to the need for better management of externalized employees and a designing new psychological contracts.

Maguire (2002) provides empirical evidence that the psychological contract is indeed changing. In particular she found that long term security is being superceded by other sources of fulfilment. Thus, loyalty has to be 'purchased' in a different way if they want flexibility and employability to dominate the psychological contract. Similarly, Hiltrop (1996) found that the new psychological contract is short-term and the employee is somehow expected to be self-reliant regarding their career and employability. At the same time the organization demands loyalty and commitment. All of this suggests that the problem for organizations will be the way in which they can provide Theory Y motivators such as sense of achievement, recognition, and team relations in what is essentially a Theory X environment. Hiltrop (1996:42) claims that because of the changing face of work people '...will not automatically be loyal to their company, but that, like professionals they will be moved by a new kind of loyalty to their disciplines and skills”.

Finally, there is ample evidence that breaches of aspects of the psychological contract as a result of decreased job security has detrimental effects on people and organizations. Some examples are: workplace tension and disharmony (Brooks and Harfield, 2000); negative health effects (Kivimaki et al, 2001; psychological ill-health (Tepper, 2001). 
The changing nature of work and the 'new' psychological contract are important factors when considering the current rush to systematizing knowledge management praxis in organizations. The researcher and the practitioner need to be quite clear about the effects of knowledge management on organizational and individual behaviour. Specifically, the question is to what extent knowledge management practices and expectations are in fact sustainable.

\section{The Psychological Contract and Knowledge Management}

Many professionals are in the same position as the labourer who was spawned by the industrial revolution, with only their labour to sell and subject to the whims of their bosses in terms of tenure and price. Now professionals have only their intellectual property, their skills and knowledge, in a market that calls the tune. The casual and contract worker, and the consultant are in an even more precarious position than the full-time employer whose tenure is also questionable. The knowledge management environment expects that workers (it is difficult to use the term employee any longer in the present work environment) will give up their knowledge, skills and ideas for a pay packet or a consultancy fee. But where is the reciprocity in terms of the psychological contract? When people feel cheated then a company can indeed expect trouble (Kolb, Rubin, and McIntyre, 1991).

Knowledge creation is both an internalised and a socialisation process. The exact conception of an idea that leads to an innovation, almost by definition, is not confined to place and time but, rather, can occur at any time (Usher, 1954). The creation of organizational knowledge, or intellectual capital, is driven by the interplay of human capital (employee knowledge and skills) needed to meet product or customers' needs, structural capital (organizational capability to respond to market demands) and customer capital (the strength of a customer base). The availability for "tinkering" or "slack" time for learning, thinking and reflecting may be one of the best vehicles for knowledge creation. Organizational climate needs to be one of learning in order to motivate individuals and groups to share knowledge (Senge, 1990; Davenport and Prusak, 1997). How leaders can develop such a climate in an environment of uncertainty and potential exploitation is a vexed issue.

The psychological contract between the worker and the employer is completely unclear regarding intellectual property. Like labour it is all the worker possesses and when it is sold there is nothing left to bargain or barter. Yet the rhetoric and dogma around knowledge management fails to take into account how any psychological contract relating to intellectual property could be anything but disadvantageous to the worker in the current world of work. In the seemingly bland accounts of how organizations need to manage knowledge in order to thrive and survive there is a hidden psychological contract: that the worker is a willing player and giver of all. Intellectual property is, like one's labour, an aspect of self. 
It is intertwined with the individual's personality. We could expect that a person will react with some distress should they feel that their intellectual property rights were violated in some knowledge management process. The potential negative fallout for the individual and the organisation have been noted above.

Given the changing nature of the psychological contract described in the previous section one might presume that tangible rewards might be increased given the insecurity of current employment. Except for executive remuneration there are few signs that this is happening. However, Hiltrop (1996) suggests that offering incentives such as development opportunities that enhance employability or what Korac-Kakabadse and Korac-Kakabadse (1998) call "career resilience". Hiltrop also suggests that human resource practices need to be aligned with social changes by providing employees with autonomy, meaningful work, participation in decision making, openness, and investing in people, for example. However, these Theory Y concepts need to go beyond rhetoric and be transformed into reality through some systematic processes. Knowledge management praxis should consider this in its relationship with human resource management.

For the individual there is a new set of coping skills that involve seeing career resilience in a positive light. These skills are: are enactment (Weick, 1996); linking (non)work agendas (Fletcher and Bailyn, 1996); networking to ensure that one might find another job; arenas of formal associations with regions, industries and projects; and becoming a repository of knowledge (Bird, 1993). All of these have direct implications to the development of intellectual property as a valued commodity. The problem for the individual and the organisation might be in the terms and conditions this knowledge is managed.

\section{Conclusion}

There is growing awareness for the need for individuals to take greater if not all responsibility for self-development, instead of relying on paternalistic approaches based on the assumption that career development is the domain of the corporate HR specialist and line mangers (Garvan, 1990). Self-development is perceived as the individual's responsibility (Pedler et al, 1986; 1991). The shift to a self-development approach requires substantial change in expectations and attitudes to career development and meanings attributed to psychological contracts (Herriot et al, 1994). The new psychological contract must be one of shared vision and mutual benefit rather than one of simple job security, corporate loyalty or the presumed needs of building knowledge management capacities.. A new psychological contract, as the basis of the employer-employee relationship, needs to help mediate the apparent contradiction in employers' efforts to decrease costs (in order to be more efficient) and increase employee involvement (in order to be more productive) (De Meuse and Tornow, 1993). 
Knowledge management praxis, as a tool to help the new organizational anorexia needs to consider this changed psychological contract. There are also implications for how intellectual property will be treated in the fine print of this contract if not the large print of more legally binding explicit contracts. From an organizational behavioural perspective a key challenge is how to promote harmony in the new organisation when distrust and a sense of injustice is more likely as the psychological contract is breached. Finally, have we reached a situation where the professional's knowledge is now synonymous with that of a person's labour during and following the industrial revolution? The professional now is the knowledge worker whose knowledge is to be exploited by the knowledge economy.

\section{Bibliography}

Bird, G. (1993), The Process of Law in Australia, Butterworth, Sydney.

Brooks, I., and Harfield, T., (2000) 'Breaking the Psychological Contract: The Effects of Change-work on Middle Managers when Implementing Organizational Change', Asia Pacific Journal of Human Resources, Volume 3, Number 3, pp. 91-103.

Brue, K., Grimshaw, D. and Myers, A. (2000), 'The Business Value of Knowledge Exploitation: A Survey of UK Industry', Report, Cranfield School of Management, Microsoft and Knowledge Management Partners, Cranfield, May.

Davenport,T.H. and Prusak, L. (1997), Information Ecology: Mastering the Information and Knowledge Environment, Oxford University Press, New York.

Davis, M.C. (1998), 'Knowledge Management', Information Strategy: The Executive Journal, Fall, pp. 11-22.

De Meuse, K.P. and Tornow, W.W. (1993), 'Leadership and the Changing Psychological Contract Between Employer and Employee', Issues and Observations, Volume 13, Number 2, pp. 32-35.

Feldman, D., Doerpinghaus, H. and Tumley, W. (1994), 'Managing Temporary Workers: A Permanent HRM Challenge', Organizational Dynamics, Volume 23, Number 2, Autumn, pp. 49-62.

Fletcher, J.K. and Bailyn, L. (1996), 'Challenging the Last Boundary: Re-connecting Work and Family', in Arthur, M.B. and Rousseau, D.M. (Eds.), Boundaryless Careers: Work, Mobility and Learning in the New Organizational Era, Oxford University Press, New York, pp. 82-96.

Garvan, T.N. (1990), 'Promoting Strategic Career Development Activities: Some Irish Experiences’, Industrial and Commercial Training, Volume 22, Number 6, pp. 2332.

Handy,C. (1995), 'Trust and the Virtual Organization', Harvard Business Review, Volume 73, Number 3 , May-June, pp. 40-49.

Herriot, P., Gibbons, P., Pemberton, C. and Jackson, R.P. (1994), 'An Empirical Model of Managerial Careers in Organization', British Journal of Management, Volume 5, Number 1, pp. 113-121.

Hiltrop, J. M., (1996), 'Managing the Changing Psychological Contract', Employee Relations, Volume 18, Number 1, pp. 36-49.

Kivimaki, M., Vahtera, J., Penatti, J., Thomson, L., Griffiths, A. and Cox, T., (2001), 'Downsizing, Changes in Work, and Self-Rated Health of Employees: A 7-Year 3Wave Panel Study’, Anxiety, Stress and Coping, Volume 14, pp. 59-73. 
Kolb, D, Rubin, E., and McIntyre, J. (1991), Organizational Psychology, Prentice-Hall, London.

Korac-Kakabadse, A. and Korac-Kakabadse, N. (1998), The Essence of Leadership, International Thomson, London.

Korac-Kakabadse, N., Korac-Kakabadse, A. and Kouzmin, A. (1998a), 'The Role of IT in Changing Psycho-Social Contracts: A Multi-Stakeholder's Perspective', Knowledge and Process Management, Volume 5, Number 2, June, pp.344-452.

Korac-Kakabadse, N., Korac-Kakabadse, A. and Kouzmin, A. (1998b), 'The Changing Nature of the Social Contract and Some Consequences', in Mazalin, A. (ed), Public Service Management: Achieving Quality Performance in the $21^{\text {st }}$ Century. EROPA/INTAN, Malaysia, pp.159-174.

Logan, N., O'Reilly, C. and Roberts, K. (1973), 'Job Satisfaction Among Part-Time and Full-Time Employees', Journal of Vocational Behaviour, Volume 3, Number 1, pp. 33-41.

Lucero, M. A. and Allen, R. E., (1994), 'Employee Benefits: A Growing Source of Contract Violations', Human Resource Management, Volume 33, Number 3, pp. 425-446.

McGregor, D. (1960), The Human Side of the Enterprise, McGraw Hill, New York.

Maguire, H., (2002), 'Psychological Contracts: Are they Still Relevant', Career Development International, Volume 7, Number 3, pp. 167-180.

Magurie, S.R. (1993), 'Employer and Occupational Tenure: An Update', Monthly Labour Review, June, pp. 45-56.

Miller, H. and Terborg, J. (1979) 'Job Attitudes of Part-Time and Full-Time Employees' Journal of Applied Psychology, Volume 64, Number 4, pp. 380-386.

Morrison, D. (1994), 'Psychological Contracts and Change', Human Resource Management, Volume 33 , Number 3, pp. 72-84.

Moskal, B. (1993), 'Company Loyalty Dies: A Victim of Neglect', Industry Week, March, pp. 11- 12.

Murray, P. and Myers, A. (1997), 'The Facts About Knowledge', Information Strategy, Volume 2, Number 7, September, pp. 29-33.

Pedler, M., Burgoyne, J. and Boydell, T.A. (1991), The Learning Company, McGrawHill, Maidenhead.

Rogers, R. W., (1995), 'The Psychological Contract of Trust-Part II', Executive Development, Volume 8, Number 2, pp. 7-15.

Rousseau, D. (1994) 'Two Ways to Change and Keep the Psychological Contract: Theory Meets Practice', Executive Summary for the International Consortium for Executive Development Research, Lausanne, Switzerland.

Rousseau, D. (2001), "Schema, Promise and Mutuality: The Building Blocks of the Psychological Contract', Journal of Occupational and Organizational Psychology, Volume 51, pp. 511-541.

Rousseau, D. and Greller, M. (1994), 'Human Resource Practices: Administrative Contract Makers’, Human Resource Management, Volume 33, Number 3, pp. 7281.

Rousseau, D.M. and McLean Parkes, J. (1993), 'The Contract of Individuals and Organizations', in Cummings, L.L. and Staw, B.M. (Eds.), Research in Organizational Behaviour: Volume 15, St. Clair, Chicago, pp. 1-43.

Schein, E.H., (1980), Organizational Psychology (Third edition), Prentice Hall, New York.

Schermerhorn, J. R., Jr., Hunt, J. G. and Osborn, R. N. (1985), Managing Organizational Behaviour (Second edition), John Wiley and Sons, New York. 
Schulz, N. (1980), Genius Loci, Academy Edition, London.

Senge, P. M. (1990), The Fifth Discipline: The Age and Practice of the Learning Organization, Century Business, London.

Sims, R. (1994), 'Human Resource Management's Role in Clarifying the New Psychological Contract', Human Resource Management, Volume 33, Number 3, pp. 37-42.

Tepper, B. J., (2001), 'Health Consequences of Organizational Injustice: Tests of Main and Interactive Effects', Organizational Behaviour and Human Decision Making Processes, Volume 86, Number 2, pp. 197-215.

Tornow, W. W. (1988), ‘Contract Re-design', Personnel Administrator, Volume 33, Number 1, pp. 97-101.

Usher, A.P. (1954), A History of Mechanical Innovation, Oxford University Press, Cambridge.

Weick, K.E. (1996), 'Enactment and the Boundaryless Career: Organization as we Work', in Arthur, M.B. and Rousseau, D.M. (Eds.), (1996), Boundaryless Careers: Work, Mobility and Learning in the New Organizational Era, Oxford University Press, New York, pp. 29-35.

Zuboff, S. (1988), In the Age of the New Machine, Basic Books, New York. 